\title{
Edible Coating for Fresh Fruit: A Review
}

\author{
Pushpendra Kumar* and Shruti Sethi
}

\begin{abstract}
Division of Food Science and Postharvest Technology, ICAR-Indian Agricultural Research Institute, New Delhi - 110 012, India
\end{abstract}

*Corresponding author

\section{A B S T R A C T}

\begin{tabular}{|l|}
\hline Ke y w o r d s \\
Edible coating, \\
$\begin{array}{l}\text { Fruit, Shelf life, } \\
\text { Modified } \\
\text { atmosphere storage }\end{array}$ \\
\hline Article Info \\
\hline $\begin{array}{l}\text { Accepted: } \\
\text { 20 April } 2018 \\
\text { Available Online: } \\
\text { 10 May 2018 }\end{array}$ \\
\hline
\end{tabular}

\section{Keywords}

Edible coating,

atmosphere storage

Accepted:

Available Online:

10 May 2018
Presently, fresh fruit are most demanded in the market because of its good nutritional value. Due to perishable nature of fruit, it has a very short shelf life. Major losses in quality and quantity of fresh fruit occur by microorganisms, insects, pre and post harvesting conditions during transport and preservation. In the modern era, the application of bio based material as a way of enhancing the shelf life of highly perishable produce is promising. Edible coatings can provide an additional protective coating for fresh produce and can also give the same effect as modified atmosphere storage in modifying internal gas composition. Recently, various coatings for preserving fruit such as plums, apples and strawberries were successfully applied.

\section{Introduction}

Edible coating is defined as a thin layer edible material applied to the fruit surface in addition to or as a replacement for natural protective waxy coatings and to provide a barrier to moisture, oxygen and solute movement for the food. Among different post-harvest management strategies of fresh fruit handling, use of edible coatings have been reported to be very useful. Edible coating is an environment friendly technology applied on many products to control moisture transfer, gas exchange or oxidation processes. They provide an additional protective coating to the produce and also give the same effect as in case of modified atmosphere storage by modifying internal gas composition. The coatings form a semi-permeable barrier to water vapour and gas exchange, leading to weight loss reduction, respiration rate modification, and delay of senescence (Tharanathan, 2003). One major advantage of using edible films and coatings is that several active ingredients can be incorporated into the polymer matrix and consumed with the food, thus enhancing safety or even nutritional and sensory attributes. Food grade additives including colourants, flavouring agents, antioxidants and antimicrobials can be added to change their composition and improve properties of 
coatings or films, which when applied on produce improve its quality (Dhall, 2012). In addition to acting as moisture and gas barriers, the coatings control microbial growth, preserve the color, texture and moisture of the product, and thus effectively extend the shelf life of the product.

Edible coatings have many advantages over other techniques, but only when the coated produce is stored at proper temperatures, which depends on the commodity. Because of the perishable nature of the fruits, the use of cold storage is necessary to delay changes related to ripening. However, cold storage often leads to the incidence of severe chilling injury symptoms. Therefore, appropriate post-harvest technologies with or without cold storage are needed of which use of edible coatings is an emerging strategy. Application of edible coatings by dip or spray method may maintain the quality of fruits for a longer time which will thus help in extending the marketability of plums for a prolonged period.

Several types of edible coatings have been applied successfully for preservation of fresh products (Park et al., 1994). Edible coatings are composed of polysaccharides, proteins, lipids or a blend of these compounds. Their presence and abundance determine the barrier properties of material with regard to water vapor, oxygen, carbon dioxide and lipid transfer in food systems (Guilbert et al., 1996). Semperfresh ${ }^{\mathrm{TM}}$, a food- grade coating used to retard moisture loss, ripening and spoilage of fruits is a mix of sucrose esters with high proportion of short chain unsaturated fatty acid esters, sodium salts of carboxymethyl cellulose and mixed mono and diglycerides (Drake et al., 1987). It is an improved formulation of earlier sucrose polyester. The major difference in this case is improved dispersion due to incorporation of higher proportion of short chain unsaturated fatty acid esters. These fruit coatings were found to be significantly effective in retention of reducing sugars, delaying changes in firmness, titratable acidity, $\mathrm{pH}$, soluble solids, ascorbic acid and pigments synthesis resulting in increased shelf life (Tasdelen and Bayindirli, 1998).

Shellac, a special natural polymer, obtained from purified resinous secretion of lac insects, (Laccifer lacca) has been widely studied as an edible film coating. It is composed of a hard resin and soft resin of polyesters and single esters containing hydroxyl and carboxyl groups (Upadhye et al., 1970). It is an excellent film forming agent with good barrier properties and is soluble in alcohol and alkaline solutions (Luangtana-Anan et al., 2007). It has been widely used in the food and agro industries for water, gas, lipid and microbial spoilage protection and hence prolonging the shelf life of these products (Valencia-Chamorro et al., 2009).

For several fruits, the purpose of waxing is to impart a shiny appearance to the fruits and to reduce weight loss by slowing down senescence during storage. Waxes act as protective films for fruits, maintaining the pulp's firmness for a longer period of time. They typically modify the atmosphere around the fruits, raising carbon dioxide levels and reducing oxygen level (Petracek et al., 1998). In this environment, fruits show lower metabolic activities, especially respiration and transpiration. These attributes can induce greater fruit resistance to pathogens, and thus increasing their shelf life.

The fruits have a natural wax coating which develops during the maturation and ripening processes. However, during rough handling of fruits, the natural shield gets destroyed 
and bruising occurs. Thus, the application of commercial food grade edible coating is important to replace this loss during the postharvest period. Coating or waxing reduces shrivelling, wilting, and respiration rate of fruits and enhances the gloss and cosmetic appearance of fruits (El-Anany et al., 2009). The use of food grade wax coating on fruits is safe and is approved for application on fresh fruits and vegetables (PFA, 2008). Edible coatings also provide additional benefit of reducing the volume of non biodegradable packaging materials (Valero et al., 2013).

Food Safety and Standards Authority of India under ministry of health and family welfare permits that fresh fruits be coated with bee wax (white and yellow) or carnauba wax or shellac wax at level not exceeding good manufacturing practices under proper label declaration as provided in Regulation 2.4 .5 (44) of Food Safety and Standards (Packaging and Labelling) regulations (FSSAI, 2011).

The present chapter is an attempt to compile a comprehensive review by critically examining scientific literature pertaining to the physical, physiological and biochemical changes in fruits in response to postharvest treatments with surface coatings. This review would provide valuable insights into what has already been achieved in fruits.

\section{Effects of edible coatings on physiological loss in weight}

Physiological loss in weight is an important parameter which determines the freshness of a fruit. Water loss can cause flesh softening, fruit ripening and senescence because of ethylene production and other metabolic reactions (Zhou et al., 2008). Two types of edible coatings were tested by Baldwin et al., (1999) for their effect on external and internal mango fruit atmospheres and quality factors during simulated commercial storage at 10 or $15^{\circ} \mathrm{C}$ with $90-99 \% \mathrm{RH}$ followed by simulated marketing conditions of $20^{\circ} \mathrm{C}$ with $56 \%$ RH. One coating was polysaccharide based while the other had carnauba wax as the main ingredient. The carnauba wax coating significantly reduced water loss compared to uncoated and polysaccharide based coating treatments. This confirmed what has been reported in the literature, that polysaccharide coatings are less permeable to respiratory gases, such as $\mathrm{O}_{2}$, and more permeable to water vapor compared to carnauba wax. Yaman and Bayoundurlc (2002) worked on sweet cherry and applied coatings of different concentration of Semperfresh $^{\mathrm{TM}} 10 \mathrm{~g} / \mathrm{L}$ and $20 \mathrm{~g} / \mathrm{L}$ and stored at two environmental conditions i.e., ambient temperature $30 \pm 3^{\circ} \mathrm{C}$ at $40-50 \%$ relative humidity and cold storage $\left(0^{\circ} \mathrm{C}\right.$ at $95-98 \%$ relative humidity). They found that Semperfresh ${ }^{\mathrm{TM}} @ 20 \mathrm{~g} / \mathrm{L}$ was most effective to reduce the weight loss of sweet cherry. Martınez-Romero et al., (2006) also reported that an aloe vera coating (1:3) was effective in delaying weight loss of sweet cherry stored at $1^{\circ} \mathrm{C}$ at $95 \% \mathrm{RH}$ as the percentage of losses were double in control samples than in aloe vera treated sweet cherry fruits. The primary mechanism of moisture loss from fresh fruits and vegetables is by vapour-phase diffusion driven by a gradient of water vapor pressure at different locations. The thickness of the barrier and moisture permeability of coatings is important factors from the view point of mass transfer rate. On the other hand, respiration causes a weight reduction because of the loss of a carbon atom from the fruit in each cycle. Weight loss of cherries in cold storage was statistically lower than in those stored at ambient temperature due to temperature effects on vapor pressure difference and increased water retention (Yaman and Bayoundurlc, 2002). Worrell et al., (2002) investigated 
that breadfruit stored at the lower temperatures $\left(12,13,14^{\circ} \mathrm{C}\right)$ showed a $20 \%$ loss in fresh weight over the first 6 days of storage compared to $32 \%$ weight loss at ambient temperatures for the same period. It has been reported by Mahajan et al., (2011) that citrashine coated pear fruits registered the lowest average physiological loss in weight $(2.82 \%)$ followed by terpenoidal oligomer $(3.12 \%)$ and carnauba coated fruits $(4.93 \%)$ from 3 to 24 days of storage as compared to the control lot $(8.38 \%)$ stored under ordinary market $\left(30-32{ }^{\circ} \mathrm{C}\right)$ and supermarket $\left(20-22^{\circ} \mathrm{C}\right)$ conditions. This increase in physiological loss in weight might be due to the higher temperatures leading to increased respiration rate and moisture loss.

\section{Effects of edible coatings on fruit firmness}

In general the fruit firmness follows a declining trend commensurate with advancement in the storage period. Yaman and Bayoundurlc (2002) worked on sweet cherry and applied Semperfresh ${ }^{\mathrm{TM}}(10,20$ $\mathrm{g} / \mathrm{L}$ ) coating, stored at ambient temperature $\left(30 \pm 3^{\circ} \mathrm{C}\right)$ and at humidity $(40-50 \% \mathrm{RH})$, and stored at cold storage $\left(0^{\circ} \mathrm{C}\right)$ and at humidity (95-98\% RH). Cherries stored at $0^{\circ} \mathrm{C}$ had higher firmness values than cherries stored at ambient temperature. So, cold temperature had a strong effect on the retention of firmness. At the same time, as the Semperfresh ${ }^{\mathrm{TM}}$ coating concentration increased, the firmness values increased. Retention of firmness can be explained by retarded degradation of insoluble protopectins to the more soluble pectic acid and pectin. During fruit ripening, depolymerization or shortening of chain length of pectin substances occurs with an increase in pectinesterase and polygalactronase activities. Low oxygen and high carbon dioxide concentrations as provided by application of coatings reduce the activities of these enzymes and allow retention of the firmness of fruits and vegetables during storage. Martınez-Romero et al., (2006) observed the aloe vera treatment significantly reduced the firmness losses (more than 50\%) during cold storage and shelf life compared with control fruit samples of sweet cherry. The softening process in sweet cherries has been reported to be dependent on the increase in polygalacturonase, $\beta$-galactosidase and pectin methylesterase activities.

\section{Effects of edible coatings on peel colour}

Peel colour is most important quality parameter of fruits which influence consumer appeal as well as internal condition. Baldwin et al., (1999) reported that beneficial effects of carnauba wax included improvement of appearance and an attractive natural looking sheen to the fruits. Vargas et al., (2006) worked on strawberries cultivar Camarosa. Chitosan $(1 \%, \mathrm{w} / \mathrm{v})$ with oleic acid was coated on strawberries which were then cold stored at $4^{\circ} \mathrm{C}$ for 10 days. They found that no significant differences in terms of hue or chroma were found due to coatings. Coatings led to a decrease in luminosity of samples which became significant chroma and hue in coated samples did not change significantly during storage, although uncoated strawberries were slightly lower in hue and chroma which can also be attributed to the surface drying.

\section{Effects of edible coatings on physiological attributes}

\section{Effects of edible coatings on respiration and ethylene production}

Respiration rate of stored fruits has been found to increase with the advancement of storage period. Worrell et al., (2002) reported that low temperature storage of 
breadfruit at $13^{\circ} \mathrm{C}$ doubled the shelf life of the fruit to about $10 \mathrm{~d}$ by delaying the onset of the climacteric. All the coatings investigated delayed fruit softening slightly at both ambient temperature and $13^{\circ} \mathrm{C}$, possibly by depressing internal $\mathrm{O}_{2}$ and increasing internal $\mathrm{CO}_{2}$ concentrations. Breadfruit showed a comparatively high basal $\mathrm{CO}_{2}$ production rate of $20-50 \mathrm{ml} \mathrm{kg}^{-1}$ $\mathrm{h}^{-1}$ as might be expected for such a perishable commodity. When fruits were stored at $13^{\circ} \mathrm{C}$, peak $\mathrm{CO}_{2}$ production $(300 \mathrm{ml}$ $\mathrm{kg}^{-1} \mathrm{~h}^{-1}$ ) was reduced to one fifth of its value at ambient temperature between 10-16 d postharvest compared to 5-6 d postharvest at ambient temperature. Since the peaks for carbon dioxide and ethylene $\left(\mathrm{C}_{2} \mathrm{H}_{4}\right)$ production coincide, the same delay was seen in $\mathrm{C}_{2} \mathrm{H}_{4}$ production at $13{ }^{\circ} \mathrm{C}$ as for $\mathrm{CO}_{2}$ but the lower temperature depressed peak of $\mathrm{C}_{2} \mathrm{H}_{4}$ production (1.5/l kg-1h-1) about eightfold. Velickova et al., (2013) studied that in strawberries cv. Camarosa coated with different materials such as chitosan $(0.8$ $\mathrm{g} / 100 \mathrm{~g})$ with acetic acid $(1 \mathrm{ml} / 100 \mathrm{ml})$ and $0.2 \mathrm{~g}$ of glycerol and $0.2 \mathrm{~g}$ of tween 80 , beeswax coatings $(0.5 \mathrm{~g} / 100 \mathrm{~g})$ with $25 \%$ of tween 80 and three layer coating consisting of separate bee wax-chitosan-bee wax layer, composite coating $(0.8 \mathrm{~g} / 100 \mathrm{~g}$ chitosan and $10 \mathrm{~g} / 100 \mathrm{~g}$ bee wax emulsion), the coatings controlled the exchange of the gases between the fruit and the environment due to their different permeability to gases like $\mathrm{CO}_{2}$ and $\mathrm{O}_{2}$. Incorporation of the beeswax in the coating significantly reduced the respiration rate of the strawberries and hence resulted in better preservation.

\section{Effects of edible coatings on biochemical and quality attributes}

Effects of edible coatings on total soluble solids, titratable acidity and ascorbic acid

It was observed by Yaman and Bayoundurlc (2002) that in sweet cherries acidity increased with increasing Semperfresh ${ }^{\mathrm{TM}}$ concentrations. Semperfresh ${ }^{\mathrm{TM}}$ coatings were effective in reducing the ascorbic acid loss for both ambient $\left(30^{\circ} \mathrm{C}\right)$ at $40-50 \%$ relative humidity and cold storage $\left(0^{\circ} \mathrm{C}\right)$ at 95-98\% relative humidity conditions. The reduction of ascorbic acid loss in coated cherries was due to the low oxygen permeability of sucrose polyester coating which lowered the activity of the enzymes and prevented oxidation of ascorbic acid. The effect of low temperature significantly reduced the ascorbic acid loss. This showed the effect of temperature on the activities of the related enzymes. Ascorbic acid is lost due to the activities of phenoloxidase and ascorbic acid oxidase enzymes during storage. Semperfresh ${ }^{\text {TM }}$ showed the maximum rise in total sugars and the maximum fall in starch content. Zhou et al., (2008) worked with pear cv. Huanghua. Coatings applied were shellac $(14.3 \mathrm{gm} / 100$ $\mathrm{ml}$ water), Semperfresh ${ }^{\mathrm{TM}}(1.0 \mathrm{gm} / 100 \mathrm{ml}$ water), carboxy methyl chitosan (2.0 $\mathrm{g} / 100 \mathrm{~mL}$ water) during cold storage $\left(4^{\circ} \mathrm{C}\right)$. The total soluble solids, titratable acidity and ascorbic acid levels in pears decreased significantly in all treatments after 60 days of storage. Compared with the control samples, the shellac coated pears had significantly higher total soluble solids, titratable acidity and ascorbic acid levels. Soluble solids and organic acids of fruits are substrates that are consumed by respiration during storage. Ascorbic acid is primarily regulated by ascorbic acid oxidase and phenoloxidase, whose activities are influenced by the oxygen content in the storage condition. In this study, shellac coating was more effective in the retention of total soluble solids and the titratable acidity and ascorbic acid levels because of the lower gas permeability of shellac coating that inhibited the respiratory rates and retarded the overall metabolic activities of pears during storage. 


\section{Effects of edible coatings on anthocyanins}

Valero et al., (2013) reported that the skin colour in purple plums is due to anthocyanins, the main anthocyanin quantified in 'Blackamber' and 'Larry Ann' plums being cyanidin 3-glucoside followed by cyanidin 3-rutinoside, as previously reported for these and other purple plum cultivars. Both anthocyanins increased with the progress of cold storage, the increase being lower in alginate coated plums than in control ones. Thus, alginate treatment delayed colour change in purple plum cultivars by retarding the anthocyanin synthesis associated to the postharvest ripening process (Serrano et al., 2009; DiazMula et al., 2012).

\section{Effects of edible coatings on pectin methyl esterase activity}

Khan and Singh (2009) reported that postharvest fruit softening is associated with activities of cell wall hydrolysis enzymes. Pectin methyl esterase and polygalacturonase have been reported as key enzymes involved in fruit softening. Activities of pectin methyl esterase into control fruit skin and pulp tissues increased with extended storage time, while in 1-MCP treated fruit skin and pulp tissues of 'Tegan Blue' Japanese plum, pectin methyl esterase activity was less during storage with increase in concentration of 1-MCP applied. 1-MCP-treated fruit skin tissues exhibited $38.5 \%$ reduction in activities of pectin methyl esterase after 3 and 6 weeks of storage compared with untreated fruits. After 3 weeks of storage, untreated fruit pulp tissues exhibited $25.7 \%$ and $42.9 \%$ higher pectin methyl esterase activity than fruit treated with 1-MCP. Pulp tissues showed 1.5-fold higher mean pectin methyl esterase activity than the skin tissues.
Effects of edible coatings on lipid peroxidation / Malondialadehyde content

Larrigaudière et al., (2001) observed that in 'Blanquilla' pears, lipid peroxidation activity in fruits under optimum controlled atmosphere $\left(2 \% \mathrm{O}_{2}+0.7 \% \mathrm{CO}_{2}\right)$ was significantly lower than under stressful atmospheres high in $\mathrm{CO}_{2}$ having $2 \% \mathrm{O}_{2}+$ $5 \% \quad \mathrm{CO}_{2}$. The lower lipid peroxidation activity was also associated with the lower core browning in the pears held under optimum controlled atmosphere. These observations supported the role of lipid peroxidation in occurrence of physiological disorders in fruits. They suggested that the lipid peroxidation activity during postharvest storage can be triggered by stresses such as low temperature, stressful atmospheres and a combination of both, which caused enhanced lipid peroxidation leading to initiation of certain physiological disorders and senescence-related processes.

\section{References}

Baldwin, E. A., Burns, J. K. and Kazokas, W. 1999. Effect of two edible coatings with permeability characteristics on mango (Mangifera indica L.) ripening during storage. Postharvest Biol. Technol., 17: 215-226.

Dhall, R. K. 2012. Advances in edible coatings for fresh fruits and vegetables: A Review. Crit. Rev. Food Sci. Nutr., 53: 435-450.

Diaz-Mula, H. D., Serrano, M. and Valero, D. 2012. Alginate coatings preserve fruit quality and bioactive compounds during storage of sweet cherry fruit. Food and Bioprocess Technol., 5: 2990-2997.

Drake, S. R., Fellman, J. K. and Nelson, J. W. 1987. Postharvest use of sucrose polyesters for extending the shelf-life 
of stored 'Golden Delicious' apples. J. Food Sci., 52: 1283-1285.

El-Anany, A. M., Hassan, G. F. A. and Ali, F. M. R. 2009. Effect of edible coatings on the shelf life and quality of 'Anna' apple (Malus domestica Borkh.) during cold storage. J. Food Technol., 7: 5-11.

FSSAI, 2011. Food Safety and Standards Authority of India, Ministry of Health and Family Welfare, The Gazette of India: Extraordinary (Part III-Sec. 4). Guilbert, S., Gontard, N. and Gorris, L. G. M. 1996. Prolongation of the shelf life of perishable food products using biodegradable films and coatings. Lebensm.-Wiss- Technol., 29: 10-17.

Kester, J. J. and Fennema, O. R. 1986. Edible films and coatings: A review. Food Technol., 40: 47-59.

Khan, A. S. and Singh, Z. 2009. 1-MCP application suppresses ethylene biosynthesis and retards fruit softening during cold storage of 'Tegan Blue' Japanese plum. Plant Science, 176: 539-544.

Krochta, J. M. and Mulder-Johnston, C. D. 1997. Edible and biodegradable polymer films: Challenges and opportunities. Food Technol., 51:6174.

Larrigaudière, C., Pintó, E., Lentheric, I. and Vendrell, M. 2001. Involvement of oxidative processes in the development of core browning in controlled-atmosphere stored pears. $J$. Hort. Sci. Biotech., 76: 157-162.

Luangtana-anan, M., Limmatvapirat, S., Nunthanid, J., Wanawongthai, C., Chalongsuk, R. R and Puttipipatkhachorn, S. 2007. Effect of salts and plasticizers on stability of shellac film. J. Agric. Fd. Chem., 55: 687-692.

Mahajan, B. V. C., Singh, J. and Dhillon, W. S. 2011. Effect of different edible coatings on quality and shelf life of pears under supermarket and ordinary market conditions. International Journal Fruit Science, 11: 207-219.

Martınez-Romero, D., Alburquerque, N., Valverde, J. M., Guillen, F., Castillo, S., Valero, D. and Serrano, M. 2006. Postharvest sweet cherry quality and safety maintenance by Aloe vera treatment: A new edible coating. Postharvest Biol. Technol., 39: 93100.

McHugh, T. H. and Senesi, E. 2000. Apple wraps: A novel method to improve the quality and extend the shelf life of fresh-cut apples. J. Food Sci., 65: 480485.

Park, H. J. 1999. Development of advanced edible coatings for fruits. Trends Food Sci Technol., 10: 254-260.

Park, H. J., Chinnan, M. S. and Shewfelt, R. L. 1994. Edible corn-zein film coatings to extend storage life of tomatoes. J. Food Process. Preserv., 18: 317-331.

Petracek, P. D., Dou, H. and Pao, S. 1998. Influence of applied waxes on postharvest physiological behaviour and pitting of white grapefruit. Postharvest Biol. Technol., 14: 99106.

PFA. 2008. Prevention of Food Adulteration Act, $19^{\text {th }}$ edn. International Law Book Co., Delhi, India

Serrano, M., Díaz-Mula, H. M., Zapata, P. J., Castillo, S., Guillén, F., MartínezRomero, D., Valverde, J. M. and Valero, D. 2009. Maturity stage at harvest determines the fruit quality and antioxidant potential alter storage of sweet cherry cultivars. J. Agric Food Chem., 57: 3240-3246.

Tasdelen, O. and Bayindirli, L. 1998. Controlled atmosphere storage and edible coating effects on storage life 
and quality of tomatoes. J. Food Proc. Preserv., 22: 303-320.

Tharanathan, R. N. 2003. Biodegradable films and composite coatings: past, present and future. Trends Food Sci Technol., 14: 71-78.

Upadhye, A. B., Wadia, M. S., Mhaskar, V. V. and Dev, S. 1970. Chemistry of lac resin-IV: Pure lac resin-1: Isolation and quantitative determination of constituent acids. Tetrahedron, 26: 4177-4187.

Valencia-Chamorro, S. A., Pérez-Gago, M. B., del Río, M. and Palou, L. 2009. Effect of antifungal hydroxypropyl methylcellulose (HPMC)-lipid edible composite coatings on postharvest decay development and quality attributes of cold stored Valencia' oranges. Postharvest Biol. and Technol., 54: 72-79.

Valero, D., Mula-diaz, H. M. and Zapata, P. J. 2013. Effect of alginate edible coating on preserving fruit quality in four plum cultivars during postharvest storage. Postharvest Biol. and Technol., 77: 1-6.

Vargas, M., Albors, A., Chiralt, A. and Gonzalez-Martınez, C. 2006. Quality of cold-stored strawberries as affected by chitosan-oleic acid edible coatings. Postharvest Biol. Technol., 41: 164171.

\section{How to cite this article:}

Pushpendra Kumar and Shruti Sethi. 2018. Edible Coating for Fresh Fruit: A Review. Int.J.Curr.Microbiol.App.Sci. 7(05): 2619-2626. doi: https://doi.org/10.20546/ijcmas.2018.705.303
Velickova, E., Winkelhausen, E., Kuzmanova, S. and Alves, B. D. 2013. Impact of chitosan-beeswax edible coatings on the quality of fresh strawberries (Fragaria ananassa cv Camarosa) under commercial storage conditions. Food Sci. Technol., 52: 80-92.

Worrell, D. B., Carrington, C. M. S. and Huber, D. J. 2002. The use of low temperature and coatings to maintain storage quality of breadfruit, Artocarpus altilis (Parks.) Fosb. Postharvest Biol. Technol., 25: 33-40.

Yaman, O. and Bayoundurlc, L. 2002. Effect of an edible coating and cold storage on shelf life and quality of cherries. Lebensm-Wiss-U-Technol, 35: 146-150.

Yang, Z., Zheng, Y., Cao, S., Tang, S., Ma, S. and Li, N. 2007. Effects of storage temperature on textural properties of Chinese bayberry fruit. J. Texture Stud., 38: 166-177.

Zhou, R., Mo, Y. and Li, Y. 2008. Quality and internal characteristics of huanghua pears (Pyrus pyrifolia Nakai, cv. Huanhhua) treated with different kinds of coating during storage. Postharvest Biol. Technol., 49:171-179. 